\title{
Marine habitats of juvenile southern elephant seals from Marion Island
}

\author{
Cheryl A. Tosh ${ }^{1, *}$, Jumari Steyn ${ }^{1}$, Horst Bornemann ${ }^{2}$, John van den Hoff ${ }^{3}$, \\ Brent S. Stewart ${ }^{4}$, Joachim Plötz ${ }^{2}$, Marthán N. Bester ${ }^{1}$ \\ ${ }^{1}$ Mammal Research Institute, Department of Zoology and Entomology, University of Pretoria, Private Bag X20, Hatfield 0028, \\ South Africa \\ ${ }^{2}$ Alfred Wegener Institute for Polar and Marine Research, Postfach 120161, 27515 Bremerhaven, Germany \\ ${ }^{3}$ Australian Antarctic Division, Channel Highway, Kingston, Tasmania 7050, Australia \\ ${ }^{4}$ Hubbs-SeaWorld Research Institute, 2595 Ingraham Street, San Diego, California 92109, USA
}

\begin{abstract}
Marine mammals forage in dynamic environments characterized by variables that are continuously changing in relation to large-scale oceanographic processes. In the present study, behavioural states of satellite-tagged juvenile southern elephant seals $(n=16)$ from Marion Island were assessed for each reliable location, using variation in turning angle and speed in a state-space modelling framework. A mixed modelling approach was used to analyse the behavioural response of juvenile southern elephant seals to sea-surface temperature and proximity to frontal and bathymetric features. The findings emphasised the importance of frontal features as potentially rewarding areas for foraging juvenile southern elephant seals and provided further evidence of the importance of the area west of Marion Island for higher trophic-level predators. The importance of bathymetric features during the transit phase of juvenile southern elephant seal migrations indicates the use of these features as possible navigational cues.
\end{abstract}

KEY WORDS: Marion Island · Southern elephant seals · Juveniles $\cdot$ Frontal features

\section{INTRODUCTION}

The sub-Antarctic Prince Edward Islands $\left(46^{\circ} 50^{\prime} \mathrm{S}\right.$, $37^{\circ} 50^{\prime} \mathrm{E}$ ) form an isolated island group with a climate that is driven by prevailing regional atmospheric circulation patterns (Rouault et al. 2005). Changes in local climatic conditions that have been documented for one of the 2 islands in the group, Marion Island (Smith 2002, le Roux \& McGeoch 2008), may be linked to changes in the semi-annual oscillation event in the southern hemisphere (Rouault et al. 2005) or changes in large-scale ocean dynamics (Hall \& Visbeck 2002), among other factors. These changes in atmospheric circulation patterns and large-scale ocean dynamics are reflected in changing seasurface temperature gradients at midlatitudes (Simmonds \& Jones 1998, Mo 2000). Although it may be obvious in its manifestation (le Roux \& McGeoch 2008), the exact consequences of these changes in oceanographic conditions for highly mobile marine mammals are difficult to predict and require longterm studies to define and understand foraging ranges and habitats (Simmonds \& Isaac 2007). Ageand sex-related responses to environmental variables also need to be considered in order to make accurate predictions about the consequences of environmental variability on a species, especially for sexually dimorphic species that may display sex-related segregation in some behaviours, such as the selection of foraging grounds and diving behaviour (McIntyre et al. 2010).

Several studies correlated foraging movements of both northern and southern elephant seals Mirounga spp. and variability in regional oceanographic conditions (Crocker et al. 2006, Biuw et al. 2007, 2010). 
Southern elephant seals $M$. leonina make long seasonal migrations to find suitable foraging areas (McConnell et al. 1992, Campagna et al. 2000, Bradshaw et al. 2004, Bailleul et al. 2007, Tosh et al. 2009). Different populations of southern elephant seals evidently use different areas of the Southern Ocean depending on where they haul out to breed and moult (Campagna et al. 2006, Biuw et al. 2007). Recently weaned pups and 1 yr olds (i.e. yearlings) appear to forage closest to their birth sites (Bornemann et al. 2000, McConnell et al. 2002, van den Hoff et al. 2002). Sexual dimorphism is not yet apparent in young seals, but young seals are more limited in their foraging abilities than adults (Stewart 1997, van den Hoff et al. 2002). The foraging movements of weaned pups and yearlings is important because survival of these age classes is generally low (Hindell et al. 1991, Pistorius \& Bester 2002, McMahon et al. 2003) and may be more sensitive to variability in oceanographic conditions, prey distribution and abundance than older age classes (Field et al. 2007). All juvenile southern elephant seals perform an initial migration after weaning; this migration is thought to be genetically programmed and occurs without any prior knowledge of the surrounding region (Bornemann et al. 2000). Juveniles at Marion Island may return to their birth sites for a subsequent winter haul-out (Kirkman et al. 2001) and will generally return to sea before returning to moult early in the following summer (Kirkman et al. 2003).

Southern elephant seals born at Marion Island must quickly learn to survive in a highly variable environment. Oceanographic conditions surrounding Marion Island are dominated by the Antarctic Circumpolar Current (ACC). The ACC is bounded in the north by the Subantarctic Front (SAF) and in the south by the Antarctic Polar Front (APF). These frontal features are characterised by strong temperature, salinity and density gradients (Belkin \& Gordon 1996, Bost et al. 2009). Increased vertical mixing due to interactions between water masses and bathymetric features is often observed close to frontal features (Bost et al. 2009). The fronts of the ACC, in the vicinity of the Southwest Indian Ridge (SWIR), close to Marion Island, are considered to be variable in terms of structure and position (Durgadoo et al. 2010).

The region west of Marion Island is also characterised by higher than average kinetic energy created by the presence of eddies arising from interaction of the ACC with the regional bottom topography (Ansorge et al. 1999, Ansorge \& Lutjeharms 2005). Mesoscale eddies are counter-current waterbodies within greater currents and are responsible for the transfer of the physical energy of the ocean water to trophic energy (Bakun 2006). The physical flow properties of eddies in relation to the surrounding water masses can cause enrichment, concentration and retention of resources, creating favourable foraging grounds for ocean predators (Bakun 2006), such as birds (Nel et al. 2001, Cotté et al. 2007), sea-turtles (Polovina et al. 2006), fur seals (de Bruyn et al. 2009a) and southern elephant seals (Campagna et al. 2006, Bailleul et al. 2010, Dragon et al. 2010).

Movements of juvenile elephant seals have been previously studied at Macquarie Island (Hindell et al. 1999, McConnell et al. 2002, van den Hoff et al. 2002, Field et al. 2005) and at King George Island off the Antarctic Peninsula (Bornemann et al. 2000). At Macquarie Island, young seals foraged near the APF (McConnell et al. 2002) and the Campbell Plateau (van den Hoff et al. 2002). At King George Island, weaned pups showed no individual variation, all foraging in the open sea west of the De Gerlache Seamounts that lie to the west of the Antarctic Peninsula. Our study at Marion Island covers $6 \mathrm{yr}$ and assesses the variability in foraging movements of young seals in a heterogeneous and variable ocean environment.

The present study describes the movements of juvenile southern elephant seals from Marion Island. Generalised mixed effects models are used to investigate the relationship between behavioural states, namely searching or transiting, in relation to selected environmental covariates that could potentially influence feeding conditions. This research focussed on the influence of bathymetric features, frontal features and sea-surface temperatures on the behavioural state of juvenile southern elephant seals during their migrations from Marion Island.

\section{MATERIALS AND METHODS}

\section{Telemetry data}

Twenty-six satellite-linked data recorders were attached to juvenile southern elephant seals at Marion Island from 2001 through 2006 (see Table 1). The ages of seals were determined either by uniquely numbered flipper tags $(\mathrm{n}=24$; de Bruyn et al. 2008) or their body size and shape $(n=2$; e.g. Campagna et al. 2006). The results in the present study do not include the first foraging trip made after weaning. All of the animals tracked had already engaged in at least 1 foraging trip. Under-yearlings in the present study are defined as animals that are $0.5 \mathrm{yr}$ old, and 
yearlings have already turned 1 . The birth date of all elephant seals on Marion Island is 15 October, coinciding with the maximum number of females present during the elephant seal breeding season, which lasts for $3 \mathrm{wk}$.

Seals were immobilised with intramuscular injections of ketamine hydrochloride (Bester 1988, Erickson \& Bester 1993), and then telemetry instruments, prepared with a base of gauze netting, were glued to the pelage on the top of their heads using quick setting epoxy resin (Araldite ${ }^{\circledR}$, Ciba Geigy) following Fedak et al. (1983). Transmitters were either removed from sedated animals by shaving the pelage under the device to detach the device or during the moult, when devices are shed naturally with the moulting pelage.

All data were collected via the ARGOS Data Collection and Location Service and are archived and available through the data library Publishing Network for Geoscientific and Environmental Data (PANGAEA; www.pangaea.de). The list of relevant DOIs is available from the corresponding author.

Raw ARGOS location data were modelled using a state-space approach, outlined by Breed et al. (2009). This model provides location estimates from raw ARGOS location data that incorporate the inherent error associated with ARGOS location data as well as estimating either a searching (Mode 1) or travelling mode (Mode 0) at regular time intervals (Jonsen et al. 2005). A time interval of $12 \mathrm{~h}$ was chosen for the present study. The behaviour of satellitetracked animals is incorporated into animal movement models based on the assumptions that when searching, animals display slower swim speeds and larger deviations in consecutive turning angles in relation to the transiting portions of the tracks. The correlated random walk model that was fit to individual tracks is explained in detail by Breed et al. (2009). The model was fit by running 2 Markov chain Monte Carlo (MCMC) chains for 10000 iterations, with a burn-in of 7000, sampling all model parameters and each location estimate. Every fifth point of 3000 remaining samples was retained, resulting in a total of $600 \mathrm{MCMC}$ samples in each chain. A mean and a variance were calculated for each location estimate and model parameter from the 600 MCMC samples.

Movement parameters and behavioural states were estimated from the modelled tracks. In cases where double migrations were recorded, each migration was analysed separately.

A series of generalised mixed effects models (lme4 package in R) with individual as a random effect were constructed to test the influence of bathymetry
(IOC \& IHO 2003), fronts and $1^{\circ}$ gridded, weekly seasurface temperatures (Reynolds et al. 2002) on the behavioural state of locations as predicted by the state-space models (i.e. Mode $0=$ travelling and Mode $1=$ searching). Bathymetry was included in the model by categorising each location based on whether or not the location fell within a $1^{\circ}$ buffer zone of the SWIR and the ABFZ. In addition to seasurface temperature values for each location, locations were also categorised based on whether or not the location fell within $1^{\circ}$ of frontal features, namely the SAF and the APF. Buffers were drawn around features, incorporating the distance represented by $1^{\circ}$ of latitude and longitude to remain consistent with the sea-surface temperature data. The models were fit using a binomial distribution with a logit link because of the binary nature of the response variable, in this case 'mode'. Models were selected using a backward model selection process (Crawley 2007, Zuur et al. 2009). Starting with a full additive model (response $\sim$ fixed effects + random intercept), the least influential fixed effects were sequentially removed from the model. Likelihood ratio tests were used to test if there were significant differences between models with individual fixed effects retained in the final model and a NULL model. Models were run using R v. 2.12.0 (R Development Core Team 2008).

\section{RESULTS}

\section{Model performance}

Of 26 juvenile seals tracked from Marion Island (2001 to 2006), data from 16 individuals were retained and tracks shorter than $40 \mathrm{~d}$ were not analysed. The state-space model detected both behavioural states (0: travelling; 1 : searching) in 22 of the migrations analysed in the present study ( $\mathrm{n}=16$ individuals) (Fig. 1). A total of 25 migrations were analysed, and 3 tracks only showed outward movements ending before any searching behaviour was recorded. The model performed consistently across individuals, with MCMC model runs converging for all individuals. All model outputs for the state space analysis are available from the corresponding author.

\section{Spatial behaviour and oceanographic conditions}

Seven seals (GG154, OO312, BB045, BB032, BB018, BB193, BB125) (Table 1) showed outward movements of $50 \mathrm{~d}$ or longer (range: 50 to $144 \mathrm{~d}$ ) without return- 


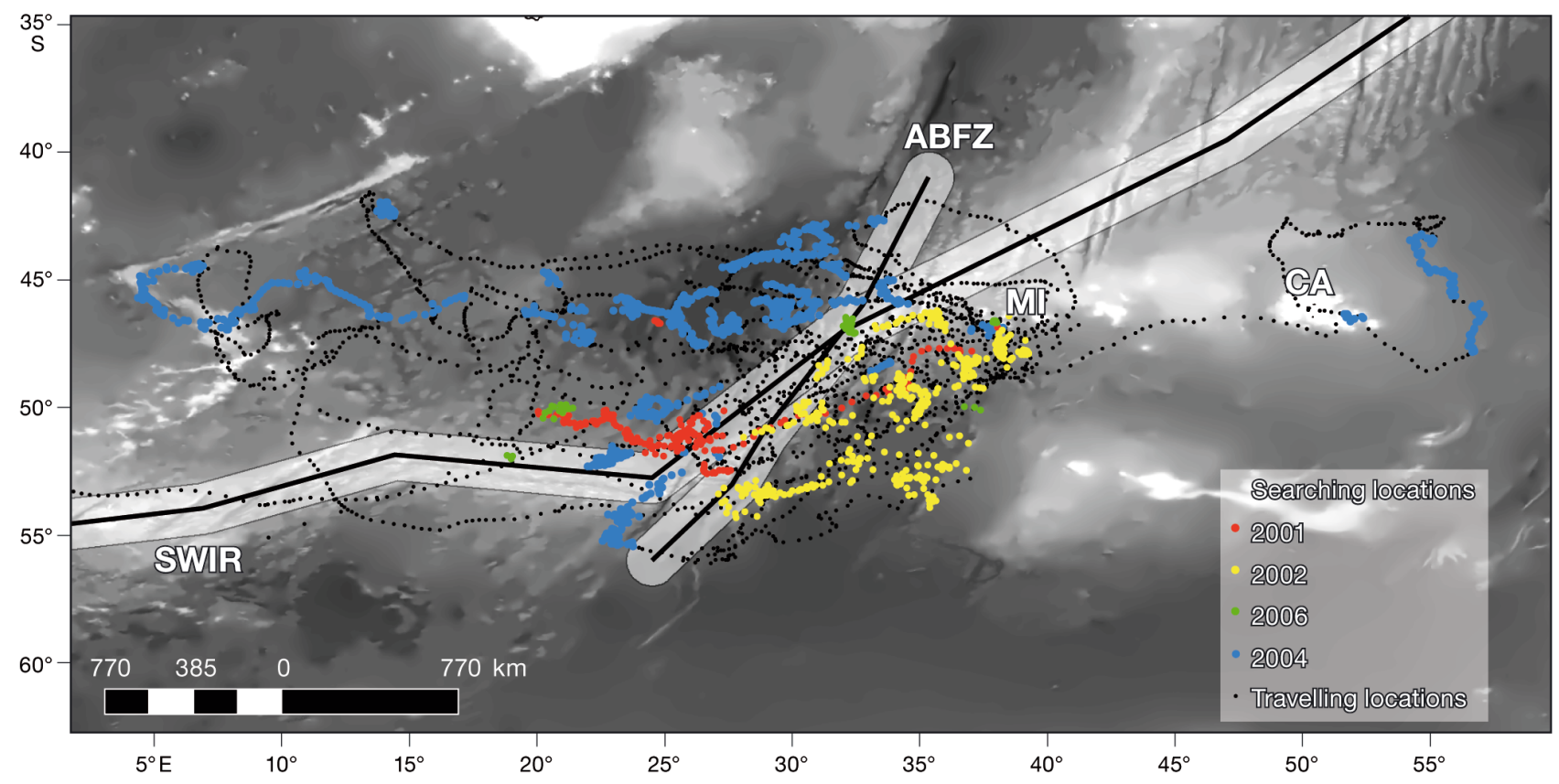

Fig. 1. State-space derived location estimates for juvenile southern elephant seals tracked from Marion Island (2001 to 2006) in relation to the bathymetry of the region. Major bathymetrical features, the Andrew Bain Fracture Zone (ABFZ) and the Southwest Indian Ridge (SWIR), are surrounded by a $1^{\circ}$ buffer. Marion Island (MI) and the Crozet Archipelago (CA) are indicated on the map. Searching locations are indicated by different colours for each year, and travelling locations are indicated in black

ing to Marion Island. Searching behaviour was recorded for 4 of these animals; 3 animals (GG154, OO312 and BB018) showed $>65 \%$ searching behaviour, starting such behaviour immediately after departure, whilst BB032 showed $<10 \%$ searching behaviour. Three of the animals did not display any searching behaviour.

Nine seals were tracked for entire (double) migrations, i.e. returning to Marion Island for the winter haul-out after an initial foraging trip and completing a second foraging trip thereafter (Table 1). Postmoulting (under-yearlings and yearlings) migrations were on average longer (104 $\pm 12 \mathrm{~d}$ ) than post-winter migrations $(82 \pm 19 \mathrm{~d})$, with the exception of 2 animals (BB277 and TO340) tracked in 2004 that recorded post-moulting trips of 62 and $42 \mathrm{~d}$ respectively as opposed to post-winter trips of 151 and $137 \mathrm{~d}$ respectively. Seven of the animals displayed searching behaviour (Mode 1 locations as predicted by the state-space analysis) in discrete bouts, flanked by locations of active travelling. One animal (WW296) recorded a complex track with $90 \%$ of locations being Mode 1 locations that were scattered throughout the track. One animal (BB277) did not display any Mode 1 locations in the post-moult migration but recorded $40 \%$ Mode 1 locations in the post-winter migration. The animals that completed double mi- grations recorded an average of $39.63 \%$ searching behaviour (range: 14 to $75 \%$ ) commencing with this behaviour on average $33 \mathrm{~d}$ (range: 0 to $88 \mathrm{~d}$ ) after departure.

The final model included 3 covariates, namely, the presence or absence of a location within $1^{\circ}$ of a frontal zone, the presence or absence of a location within $1^{\circ}$ of the SWIR and the ABFZ, and the season (Table 2). The effects of all covariates were significant $(\mathrm{p}<0.001)$. The final model had a marginally better fit than the full model, which also included sea-surface temperature. Both models were improvements against the null model, which only included 'individual' as a random effect.

The probability of searching behaviour was positively influenced if a location occurred within $1^{\circ}$ of a frontal structure. Of the $60 \%$ of searching locations found in close proximity to frontal zones, $67 \%$ were found closer to the SAF, and $33 \%$ of locations were closer to the APF. This result was not reflective of all of the years, with most of the searching locations during 2001 to 2002 and 2006 occurring in the vicinity of the $\operatorname{APF}(2001=95 \%, 2002=51 \%$ and $2006=57 \%$; Fig. 2). The only year when the SAF was preferred, 2004 (88\%), was the year with the greatest sample of individuals, which skewed the overall results (Fig. 3). The probability of searching behaviour was 
Table 1. Deployment summary for juvenile southern elephant seals from Marion Island. The migration stage, migration duration, time to first search location and the percentage of searching locations for each migration are given. Search locations were identified using state-space models. Dates given as year/mm/dd. Animals recording double migrations are featured in bold. nd: not determined

\begin{tabular}{|c|c|c|c|c|c|c|c|c|}
\hline Tag & $\begin{array}{l}\text { Sex } \\
(\mathrm{M} / \mathrm{F})\end{array}$ & $\begin{array}{l}\text { Age } \\
(\mathrm{yr})\end{array}$ & Transmitter type & $\begin{array}{c}\text { Date } \\
\text { deployed }\end{array}$ & $\begin{array}{l}\text { Migration } \\
\text { stage }\end{array}$ & $\begin{array}{l}\text { Duration } \\
\text { (d) }\end{array}$ & $\begin{array}{l}\text { Time to first } \\
\text { search (d) }\end{array}$ & $\begin{array}{c}\text { Searching } \\
\text { locations (\%) }\end{array}$ \\
\hline GG154 & F & 1 & Telonics-ST10 & $2001 / 04 / 16$ & Post-moult & 50 & 1 & 100.00 \\
\hline GG039 & $\mathbf{M}$ & 1 & Telonics-ST10 & $\begin{array}{l}2001 / 04 / 19 \\
2001 / 09 / 06\end{array}$ & $\begin{array}{l}\text { Post-moult } \\
\text { Post-winter }\end{array}$ & $\begin{array}{r}115 \\
73\end{array}$ & $\begin{array}{l}28 \\
23\end{array}$ & $\begin{array}{r}44.35 \\
5.48\end{array}$ \\
\hline OO312 & $\mathrm{F}$ & 0.5 & Telonics-ST10 & $2002 / 04 / 09$ & Post-moult & 95 & 1 & 94.05 \\
\hline WW296 & $\mathbf{M}$ & 1 & Telonics-ST10 & $\begin{array}{l}2002 / 04 / 08 \\
2002 / 08 / 12\end{array}$ & $\begin{array}{l}\text { Post-moult } \\
\text { Post-winter }\end{array}$ & $\begin{array}{l}85 \\
49\end{array}$ & $\begin{array}{l}1 \\
1\end{array}$ & $\begin{array}{l}90.59 \\
91.84\end{array}$ \\
\hline YY428 & $\mathrm{F}$ & 0.5 & $\begin{array}{l}\text { Sirtrack Kiwisat } \\
\text { Sirtrack Kiwisat }\end{array}$ & $\begin{array}{l}2004 / 04 / 13 \\
2004 / 08 / 14\end{array}$ & $\begin{array}{l}\text { Post-moult } \\
\text { Post-winter }\end{array}$ & $\begin{array}{r}120 \\
69\end{array}$ & $\begin{array}{l}29 \\
43\end{array}$ & $\begin{array}{l}44.17 \\
41.67\end{array}$ \\
\hline YY191 & $\mathbf{F}$ & 0.5 & Telonics-ST10 & $\begin{array}{l}2004 / 04 / 16 \\
2004 / 08 / 10\end{array}$ & $\begin{array}{l}\text { Post-moult } \\
\text { Post-winter }\end{array}$ & $\begin{array}{l}101 \\
105\end{array}$ & $\begin{array}{r}33 \\
5\end{array}$ & $\begin{array}{l}82.46 \\
75.00\end{array}$ \\
\hline YY232 & $\mathbf{M}$ & 0.5 & SMRU/Series 9000 SRDL & $\begin{array}{l}2004 / 04 / 15 \\
2004 / 08 / 04\end{array}$ & $\begin{array}{l}\text { Post-moult } \\
\text { Post-winter }\end{array}$ & $\begin{array}{r}102 \\
93\end{array}$ & $\begin{array}{l}26 \\
15\end{array}$ & $\begin{array}{l}46.08 \\
58.06\end{array}$ \\
\hline YY302 & $\mathbf{M}$ & 0.5 & Telonics-ST10 & $\begin{array}{l}2004 / 04 / 27 \\
2004 / 08 / 19\end{array}$ & $\begin{array}{l}\text { Post-moult } \\
\text { Post-winter }\end{array}$ & $\begin{array}{l}98 \\
95\end{array}$ & $\begin{array}{l}35 \\
15\end{array}$ & $\begin{array}{l}36.73 \\
64.21\end{array}$ \\
\hline BB277 & $\mathbf{F}$ & 1 & Sirtrack Kiwisat & $\begin{array}{l}2004 / 04 / 13 \\
2004 / 06 / 30\end{array}$ & $\begin{array}{l}\text { Post-moult } \\
\text { Post-winter }\end{array}$ & $\begin{array}{r}62 \\
151\end{array}$ & $\begin{array}{l}\text { nd } \\
27\end{array}$ & $\begin{array}{r}0.00 \\
39.74\end{array}$ \\
\hline BB045 & $\mathrm{F}$ & 1 & Sirtrack Kiwisat & $2004 / 04 / 15$ & Post-moult & 57 & 27 & 39.74 \\
\hline ВB032 & $\mathrm{F}$ & 1 & Sirtrack Kiwisat & $2004 / 04 / 15$ & Post-moult & 108 & nd & 0.00 \\
\hline ВB018 & $\mathrm{F}$ & 1 & Sirtrack Kiwisat & $2004 / 04 / 16$ & Post-moult & 122 & 58 & 10.53 \\
\hline BB193 & $\mathrm{F}$ & 1 & Sirtrack Kiwisat & $2004 / 04 / 17$ & Post-moult & 144 & 32 & 67.01 \\
\hline BB125 & M & 1 & Telonics-ST10 & $2004 / 04 / 18$ & Post-moult & 88 & nd & 0.00 \\
\hline TO340 & $\mathbf{M}$ & 1 & SMRU/Series 9000 SRDL & $\begin{array}{l}2004 / 04 / 18 \\
2004 / 06 / 27\end{array}$ & $\begin{array}{l}\text { Post-moult } \\
\text { Post-winter }\end{array}$ & $\begin{array}{r}42 \\
137\end{array}$ & $\begin{array}{l}\text { nd } \\
16\end{array}$ & $\begin{array}{r}0.00 \\
14.29\end{array}$ \\
\hline RR078 & $\mathbf{M}$ & 1 & Sirtrack/Kiwisat 101 & $\begin{array}{l}2006 / 04 / 17 \\
2006 / 09 / 03\end{array}$ & $\begin{array}{l}\text { Post-moult } \\
\text { Post-winter }\end{array}$ & $\begin{array}{r}109 \\
89\end{array}$ & $\begin{array}{l}\text { nd } \\
39\end{array}$ & $\begin{array}{l}0.00 \\
3.33\end{array}$ \\
\hline
\end{tabular}

also positively influenced by season. Locations had a higher probability of being searching locations if recorded in spring and winter.

Table 2. The results of generalized linear mixed models comparing environmental variables in 2 behavioural (0: travelling, 1: searching) modes identified by state-space models. The environmental variables were (1) proximity to a bathymetric feature $\left(0\right.$ : further than $1^{\circ}, 1$ : within $\left.1^{\circ}\right)$ (Bathy); (2) proximity to a frontal feature $\left(0\right.$ : further than $1^{\circ}, 1$ : within $1^{\circ}$ ) (Front); (3) sea-surface temperature (SST) and (4) Season. The null and full additive models are listed first, and thereafter, the models as the least influential fixed effects are removed until a model with all significant effects is achieved. Models with individual fixed effects are listed. Akaike information criterion (AIC) and $\triangle \mathrm{AIC}$ values are given to compare models. ${ }^{ \pm}$indicates the top 2 models that did not differ from each other. All models differed from the null

\begin{tabular}{|llccc|}
\hline Fixed effects & AIC & $\Delta$ AIC & Log likelihood & df \\
\hline Null & 4110.8 & 444.6 & -2051.4 & 4 \\
SST + Bathy + Front + Season $^{ \pm}$ & 3667.5 & 1.3 & -1825 & 7 \\
Bathy + Front + Season $^{ \pm}$ & 3666.2 & 0 & -1826.1 & 6 \\
SST & 4102 & 435.8 & -2046 & 5 \\
Bathy & 4047.6 & 381.4 & -2018.8 & 5 \\
Front & 3947.7 & 281.5 & -1968.8 & 5 \\
\hline
\end{tabular}

The strongest significant negative influence on the probability of foraging behaviour was whether or not a location was situated within $1^{\circ}$ of either the SWIR or the ABFZ. Of all analysed locations, $42 \%$ were within $1^{\circ}$ of the SWIR and the ABFZ, and of these, $75 \%$ were travelling locations (Fig. 1).

\section{DISCUSSION}

The movements of the juvenile seals tracked in the present study were strongly influenced by frontal and bathymetric features. Whilst searching behaviour tended to be associated with sea-surface temperature frontal structures, travelling behaviour tended to be associated with the ABFZ and the SWIR. Virtually all animals recorded searching behaviour along frontal zones, which 
are characterised by higher abundances of secondary producers compared to the open ocean (Pakhomov \& McQuaid 1996, Froneman et al. 2002, Constable et al. 2003, Bost et al. 2009). The importance of frontal structures as foraging grounds around Marion Island has been reported for subantarctic fur seals Arctocephalus tropicalis (de Bruyn et al. 2009a), greyheaded albatrosses Thalassarche chrysostoma (Nel et al. 2001) and adult female southern elephant seals (Jonker \& Bester 1998), although interfrontal zones were also targeted in the latter study.

Seals tracked in 2004 ranged toward the SAF. In 2001, 2002 and 2006, seals ranged toward the APF even though the APF was further south during these years than in 2004. Ansorge et al. (1999) suggested that availability of macrozooplankton associated with the SAF would increase when the SAF is close to Marion Island. However, when the SAF lies farther north, the PFZ broadens, resulting in the dissipation of advective forces, and trapped eddies are observed over the shelf separating Prince Edward and Marion islands (Perissinotto \& Duncombe Rae 1990), possibly resulting in higher chlorophyll a concentrations (Hunt et al. 2001). Our study shows that juvenile southern elephant seals used the SAF and did not use the shelf between Prince Edward and Marion islands when the front was situated further to the north. This may be linked to the prey species that are being targeted by juvenile southern elephant seals from Marion Island. Lanternfish (Myctophidae) and other larger prey items, such as the fish Magnisudis prionosa and the squid Martialia hyadesi, have been found in the diets of grey-headed albatross Thalassarche chrysostoma from Marion Island (Nel et al. 2001). Grey-headed albatross focused foraging effort along frontal zones and made conspicuous use of eddies (Nel et al. 2001). Although the use of eddies is not addressed in our study, it is likely that juvenile southern elephant seals from Marion Island also use these features, and further detailed studies are required for confirmation. Juvenile seals in 2004 may have been attracted to the SAF owing to the development of an intense area of heterogeneity known as the Subtropical Convergence Zone (STC). The STC is created by the interaction between the SAF, the Subtropical Front (STF) and the Agulhas Return Current and is a region of unpredictable, enhanced pelagic biomass (Barange et al. 1998) resulting from periodic blooms (Weeks \& Shillington 1996). Increased levels of chlorophyll pigmentation (indicators of primary production) are facilitated by strong frontal gradients that are created by isotherms being in close proximity to each other (Weeks \& Shillington 1996).

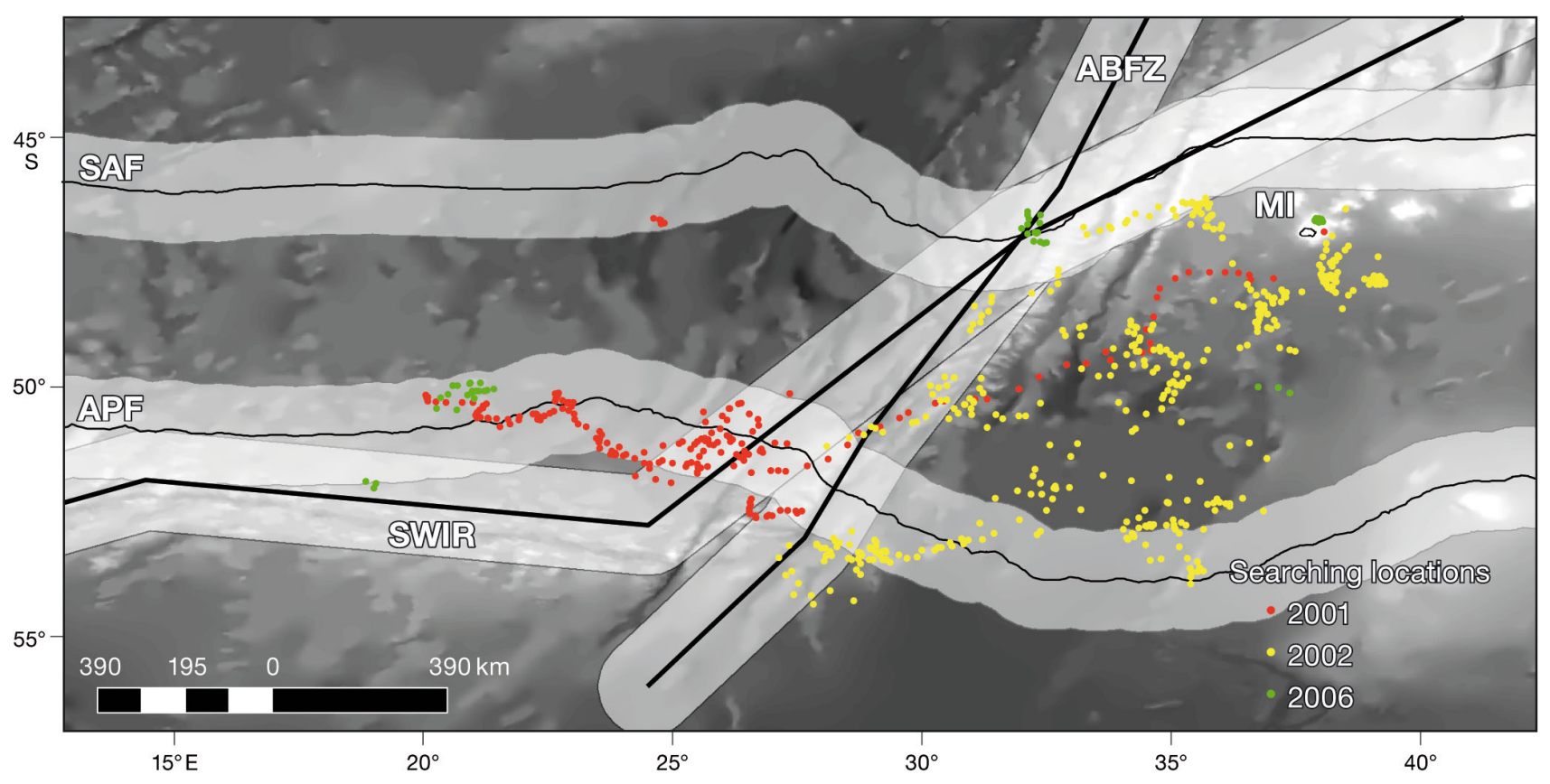

Fig. 2. State-space derived searching location estimates for juvenile seals tracked in 2001, 2002 and 2006. The Subantarctic Front (SAF) and the Antarctic Polar Front (APF), buffered by a $1^{\circ}$ zone, are indicated. Major bathymetrical features, the Andrew Bain Fracture Zone (ABFZ) and the Southwest Indian Ridge (SWIR) are surrounded by a $1^{\circ}$ buffer. Marion Island (MI) is indicated on the map 


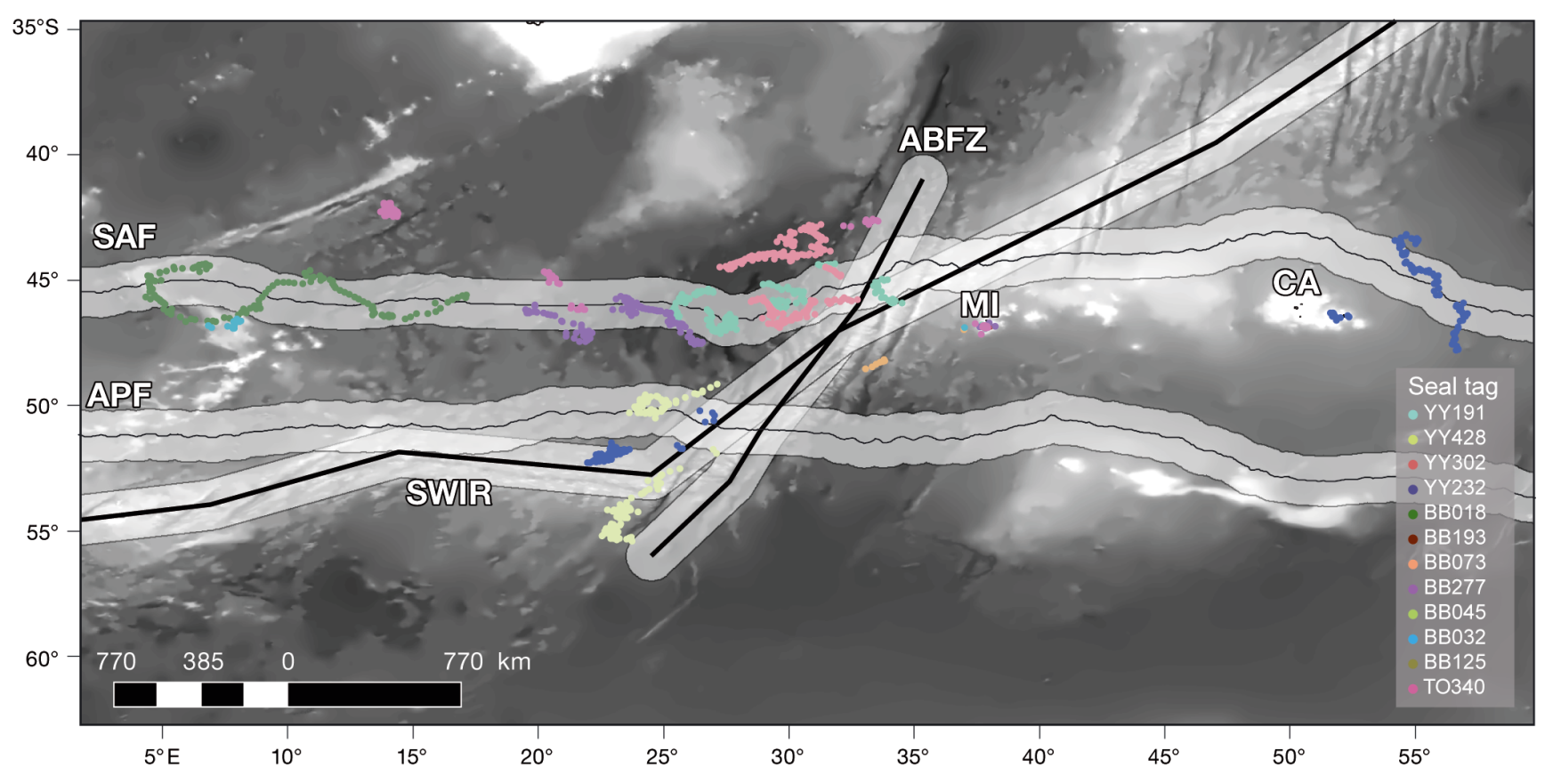

Fig. 3. State-space derived searching locations for juvenile seals tracked in 2004 (individuals are indicated in different colours). See Fig. 2 for abbreviations of major features

The strong seasonal signals evident in juvenile foraging patterns may be related to the seasonal fluctuations in frontal locations or may be an artefact of the yearly cycle that governs southern elephant seal haul-out patterns (Kirkman et al. 2001, 2003). Juvenile seals (age $=0.5$ or $1 \mathrm{yr}$ ) are known to moult early in the season, well before older seals at Marion Island (Kirkman et al. 2003). This moulting period can last for up to a month (Condy 1979) from early December to January and would explain the lack of foraging behaviour recorded during summer. New devices were only deployed on juvenile seals at the time of Marion Island relief voyages (2001, 2002, 2004 and 2006), which take place in autumn (April/May). This precluded the collection of data during January, February and March. Transiting behaviour was predominant during autumn, representing the period when most animals were travelling to their foraging areas. Juvenile southern elephant seals from Marion Island appear to behave similarly to juvenile seals from Macquarie Island, travelling in a general direction and foraging opportunistically until a suitable prey patch is found (Field et al. 2005).

The models could explain the behavioural states of seals at only $50 \%$ of locations in the present study. This may be an indication that the effects included in the models did not take all the types of foraging patches that are available to seals from Marion Island into account. For example, while frontal zones may be the most important foraging areas for juvenile seals, seals might also rely on eddies created by the flow of the ACC over the intersection of the SWIR and the ABFZ (Froneman et al. 2002, Ansorge \& Lutjeharms 2005, Bernard et al. 2007). Given that their limited foraging experience and smaller body size is likely to restrict their foraging ability (Irvine et al. 2000), juvenile seals might also use dense prey assemblages close to the sea surface and relatively close to the island. Such alternatives were not taken into account as model effects.

Of concern in tracking studies is the linkage between searching behaviour and foraging success. While we can only assume that foraging actually occurs in areas where searching behaviour has been predicted using state-space models, we cannot quantify the extent to which seals have been successful. Foraging success could be quantified using diving behaviour (e.g. Biuw et al. 2003, Thums et al. 2008), data measuring actual feeding behaviour (Liebsch et al. 2007, Naito et al. 2010) or measurement of body condition before and after foraging trips (e.g. de Bruyn et al. 2009b). Such data are vital if the links between animal movements, individual success and population dynamics (e.g. Weimerskirch et al. 2012) are to be made. 
Acknowledgements. G. Hofmeyr, P. Radzilani, T. McIntyre, N. de Buyn, C. Oosthuizen, M. Phalanndwa, R. Reisinger and T. Mufanadzo are gratefully acknowledged for their assistance with the deployments of satellite tags. The Alfred Wegener Institute for Polar and Marine Research (Germany), the Department of Science and Technology through the National Research Foundation (South Africa) and the South African National Antarctic Programme provided financial and logistical support.

\section{LITERATURE CITED}

Ansorge IJ, Lutjeharms JRE (2005) Direct observations of eddy turbulence at a ridge in the Southern Ocean. Geophys Res Lett 32:L14603 doi:10.1029/2005/GL022588

> Ansorge IJ, Froneman PW, Pakhomov EA, Lutjeharms JRE, Perissinotto R, van Ballegooyen RC (1999) Physicalbiological coupling in the waters surrounding the Prince Edward Islands (Southern Ocean). Polar Biol 21:135-145

> Bailleul F, Charrassin J, Ezraty R, Girardardhuin F, McMahon C, Field I, Guinet C (2007) Southern elephant seals from Kerguelen Islands confronted by Antarctic sea ice. Changes in movements and in diving behaviour. DeepSea Res II 54:343-355

Bailleul F, Cotté C, Guinet C (2010) Mesoscale eddies as foraging area of a deep-diving predator, the southern elephant seal. Mar Ecol Prog Ser 408:251-264

Bakun A (2006) Fronts and eddies as key structures in the habitat of marine fish larvae: opportunity, adaptive response and competitive advantage. Sci Mar 70S2: 105-122

Barange M, Pakhomov EA, Perissinotto R, Froneman PW, Verheye HM, Taunton-Clark J, Lucas MI (1998) Pelagic community structure of the subtropical convergence region south of Africa and in the mid-Atlantic Ocean. Deep-Sea Res I 45:1663-1687

Belkin IM, Gordon AL (1996) Southern Ocean fronts from the Greenwich meridian to Tasmania. J Geophys Res 101:3675-3696

- Bernard ATF, Ansorge IJ, Froneman PW, Lutjeharms JRE, Bernard KS, Swart NC (2007) Entrainment of Antarctic euphausiids across the Antarctic Polar Front by a cold eddy. Deep-Sea Res I 54:1841-1851

Bester MN (1988) Chemical restraint of Antarctic fur seals and southern elephant seals. S Afr J Wildl Res 18:57-60

- Biuw M, McConnell B, Bradshaw CJA, Burton H, Fedak M (2003) Blubber and buoyancy: monitoring the body condition of free-ranging seals using simple dive characteristics. J Exp Biol 206:3405-3423

Biuw M, Boehme L, Guinet C, Hindell M and others (2007) Variations in behaviour and condition of a southern ocean top predator in relation to in situ oceanographic conditions. Proc Natl Acad Sci USA 104:13705-13710

Biuw M, Nøst OA, Stien A, Zhou Q, Lydersen C, Kovacs KM (2010) Effects of hydrographic variability on the spatial, seasonal and diel diving patterns of southern elephant seals in the eastern Weddell Sea. PLoS ONE 5:e13816

> Bornemann H, Kreyscher M, Ramdohr S, Martin T, Carlini A, Sellmann L, Plötz J (2000) Southern elephant seal movements and Antarctic sea ice. Antarct Sci 12:3-5

Bost CA, Cotté C, Bailleul F, Cherel Y and others (2009) The importance of oceanographic fronts to marine birds and mammals of the southern oceans. J Mar Syst 78:363-376

Bradshaw C, Hindell M, Sumner M, Michael K (2004) Loyalty pays: potential life history consequences of fidelity to marine foraging regions by southern elephant seals.
Anim Behav 68:1349-1360

Breed GA, Jonsen ID, Myers RA, Bowen WD, Leonard ML (2009) Sex specific, seasonal foraging tactics of adult grey seals (Halichoerus grypus) revealed by state-space analysis. Ecology 90:3209-3221

> Campagna C, Rivas AL, Marin MR (2000) Temperature and depth profiles recorded during dives of elephant seals reflect distinct ocean environments. J Mar Syst 24: 299-312

Campagna C, Piola A, Rosamarin M, Lewis M, Fernandez T (2006) Southern elephant seal trajectories, fronts and eddies in the Brazil/Malvinas Confluence. Deep-Sea Res I 53:1907-1924

Condy PR (1979) The annual cycle of the southern elephant seal Mirounga leonina (L.) at Marion Island. S Afr J Zool 14:95-102

Constable AJ, Nicol S, Strutton PG (2003) Southern Ocean productivity in relation to spatial and temporal variation in the physical environment. J Geophys Res 108:8079 doi:10.1029/2001JC001270

Cotté C, Park YH, Guinet C, Bost CA (2007) Movements of foraging king penguins through marine mesoscale eddies. Proc Biol Sci 274:2385-2391

Crawley MJ (2007) The R book. John Wiley \& Sons, Chichester

Crocker DE, Costa DP, Le Boeuf BJ, Webb PM, Houser DS (2006) Impact of El Niño on the foraging behavior of female northern elephant seals. Mar Ecol Prog Ser 309: $1-10$

de Bruyn PJN, Tosh CA, Oosthuizen WC, Phalanndwa MV, Bester MN (2008) Temporary marking of unweaned southern elephant seal (Mirounga leonina L.) pups. S Afr J Wildl Res 38:133-137

> de Bruyn PJN, Tosh CA, Oosthuizen WC, Bester MN, Arnould JPY (2009a) Bathymetry and frontal system interactions influence seasonal foraging movements of lactating subantarctic fur seals from Marion Island. Mar Ecol Prog Ser 394:263-276

de Bruyn PJN, Bester MN, Carlini AR, Oosthuizen WC (2009b) How to weigh an elephant seal with one finger: a simple three-dimensional photogrammetric application. Aquat Biol 5:31-39

Dragon AC, Monestiez P, Bar-Hen A, Guinet C (2010) Linking foraging behaviour to physical oceanographic structures: southern elephant seals and mesoscale eddies east of Kerguelen Islands. Prog Oceanogr 87:61-71

> Durgadoo JV, Ansorge IJ, Lutjeharms JRE (2010) Oceanographic observations of eddies impacting the Prince Edward Islands, South Africa. Antarct Sci 22:211-219

Erickson AW, Bester MN (1993) Immobilization and capture. In: Laws RM (ed) Antarctic seals: research methods and techniques. Cambridge University Press, Cambridge, p 46-88

$>$ Fedak MA, Anderson SS, Curry MG (1983) Attachment of a radio tag to the fur of seals. J Zool 200:298-300

> Field IC, Bradshaw CJA, Burton HR, Hindell MA (2005) Juvenile southern elephant seals exhibit seasonal differences in energetic requirements and use of lipids and protein stores. Physiol Biochem Zool 78:491-504

Field IC, Bradshaw CJA, Burton HR, Hindell MA (2007) Differential resource allocation strategies in juvenile elephant seals in the highly seasonal Southern Ocean. Mar Ecol Prog Ser 331:281-290

Froneman PW, Ansorge IJ, Vumazonke L, Gulekana K and others (2002) Physical and biological variability in the Antarctic Polar Frontal zone: report on research cruise 103 of the MV SA Agulhas. S Afr J Sci 98:534-536 
Hall A, Visbeck M (2002) Synchronous variability in the Southern Hemisphere atmosphere, sea ice, and ocean resulting from the annular mode. J Clim 15:3043-3057

Hindell MA, Burton HR, Slip DJ (1991) Foraging areas of southern elephant seals, Mirounga leonina, as inferred from water temperature data. Aust J Mar Freshw Res 42: 115-128

Hindell MA, McConnell BJ, Fedak MA, Slip DJ, Burton HR, Reijnders PJH, McMahon CR (1999) Environmental and physiological determinants of successful foraging by naïve southern elephant seal pups during their first trip to sea. Can J Zool 77:1807-1821

> Hunt BPV, Pakhomov EA, McQuaid CD (2001) Short term variation and long term changes in the oceanographic environment and zooplankton community in the vicinity of a sub-Antarctic archipelago. Mar Biol 138:369-381

IOC \& IHO (Intergovernmental Oceanographic Commission \& International Hydrographic Organisation) (2003) 'Centenary Edition of the GEBCO Digital Atlas', published on CD-ROM 51 on behalf of the IOC and IHO as part of the General Bathymetric Chart of the Oceans. British Oceanographic Data Centre, Liverpool

- Irvine LG, Hindell MA, van den Hoff J, Burton HR (2000) The influence of body size on dive duration of underyearling southern elephant seals (Mirounga leonina). J Zool (Lond) 251:463-471

> Jonker FC, Bester MN (1998) Seasonal movements and foraging areas of adult southern female elephant seals, Mirounga leonina, from Marion Island. Antarct Sci 10: 21-30

Jonsen ID, Mills Flemming J, Myers RA (2005) Robust statespace modelling of animal movement data. Ecology 86: 2874-2884

Kirkman SP, Bester MN, Pistorius PA, Hofmeyr GJG, Owen $\mathrm{R}$, Mecenero S (2001) Participation in the winter haulout by southern elephant seals (Mirounga leonina). Antarct Sci 13:380-384

Kirkman SP, Bester MN, Pistorius PA, Hofmeyr GJG, Jonker FC, Owen R, Strydom N (2003) Variation in the timing of moult in southern elephant seals at Marion Island. S Afr J Wildl Res 33:79-84

le Roux PC, McGeoch MA (2008) Changes in climate extremes, variability and signature on sub-Antarctic Marion Island. Clim Change 86:309-329

Liebsch N, Wilson RP, Bornemann H, Adelung D, Plötz J (2007) Mouthing off about fish capture: jaw movement in pinnipeds reveals the real secrets of ingestion. Deep-Sea Res II 54:256-269

McConnell BJ, Chambers C, Fedak MA (1992) Foraging ecology and southern elephant seals in relation to bathymetry and productivity of the Southern Ocean. Antarct Sci 4:393-398

McConnell BJ, Fedak MA, Burton HR, Engelhard GH, Reijnders PJH (2002) Movements and foraging areas of naive, recently weaned southern elephant seal pups. J Anim Ecol 71:65-78

> McIntyre T, Tosh CA, Plötz J, Bornemann H, Bester MN (2010) Segregation in a sexually dimorphic mammal: a mixed-effects modelling analysis of diving behaviour in southern elephant seals. Mar Ecol Prog Ser 412:293-304

> McMahon CR, Burton HR, Bester MN (2003) A demographic comparison of two southern elephant seal populations. J Anim Ecol 72:61-74

Mo KC (2000) Relationships between low-frequency variability in the Southern Hemisphere and sea surface temperature anomalies. J Clim 13:3599-3610
Naito Y, Bornemann H, Takahashi A, McIntyre T, Plötz J (2010) Fine-scale feeding behaviour of Weddell seals revealed by a mandible accelerometer. Polar Sci 4: 309-316

Nel DC, Lutjeharms JRE, Pakhomov EA, Ansorge IJ, Ryan PG, Klages NTW (2001) Exploitation of mesoscale oceanographic features by grey-headed albatross Thalassarche chrysostoma in the southern Indian Ocean. Mar Ecol Prog Ser 217:15-26

Pakhomov EA, McQuaid CD (1996) Distribution of zooplankton and surface zooplankton across the Southern Ocean. Polar Biol 16:271-286

Perissinotto R, Duncombe Rae CM (1990) Occurrence of anti-cyclonic eddies on the Prince Edward Plateau (Southern Ocean): effects on phytoplankton biomass and production. Deep-Sea Res 37:777-793

Pistorius PA, Bester MN (2002) Juvenile survival and population regulation in southern elephant seals at Marion Island. Afr Zool 37:35-41

Polovina JJ, Uchida I, Balazs GH, Howell EA, Parker DM, Dutton MP (2006) The Kuroshio extension bifurcation region: a pelagic hotspot for juvenile loggerhead sea turtles. Deep-Sea Res I 53:326-339

R Development Core Team (2008) R: A language and environment for statistical computing. R Foundation for Statistical Computing, Vienna. www.R-project.org

Reynolds RW, Rayner NA, Smith TM, Stokes DC, Wang W (2002) An improved in situ and satellite SST analysis for climate. J Clim 15:1609-1652

Rouault M, Mélice JL, Reason CJC, Lutjeharms JRE (2005) Climate variability at Marion Island, Southern Ocean, since 1960. J Geophys Res 110:C05007 doi:10.1029/2004 JC002492

Simmonds MP, Isaac SJ (2007) The impacts of climate change on marine mammals: early signs of significant problems. Oryx 41:19-26

Simmonds I, Jones DA (1998) The mean structure and temporal variability of the semiannual oscillation in the southern extratropics. Int J Climatol 18:473-504

> Smith VR (2002) Climate change in the sub-Antarctic: an illustration from Marion Island. Clim Change 52:345-357

Stewart BS (1997) Ontogeny of differential migration and sexual segregation in northern elephant seals. J Mammal 78:1101-1116

> Thums M, Bradshaw CJA, Hindell MA (2008) Tracking changes in relative body condition of southern elephant seals using swim speed data. Mar Ecol Prog Ser 370: 249-261

Tosh CA, Bornemann H, Ramdohr S, Schröder M and others (2009) Adult male southern elephant seals from King George Island utilize the Weddell Sea. Antarct Sci 21: 113-121

van den Hoff J, Burton HR, Hindell MA, Sumner MD, McMahon CR (2002) Migrations and foraging of juvenile southern elephant seals from Macquarie Island within CCAMLR managed areas. Antarct Sci 14:134-145

Weeks SJ, Shillington FA (1996) Phytoplankton pigment distribution and frontal structure in the subtropical convergence region south of Africa. Deep-Sea Res I 43: 739-768

- Weimerskirch H, Louzao M, de Grissac S, Delord K (2012) Changes in wind pattern alter albatross distribution and life-history traits. Science 335:211-214

Zuur AE, Ieno EN, Walker NJ, Saveliev AA, Smith G (2009) Mixed effects models and extensions in ecology with R. Springer, New York, NY

Submitted: August 26, 2011; Accepted: July 23, 2012

Proofs received from author(s): October 16, 2012 